\section{ORDERING SHERPA LIFE THROUGH THEIR RITUALS: SYMBOLIC/INTERPRETATIVE PERSPECTIVE \\ (A REVIEW OF "SHERPAS THROUGH THEIR RITUALS” BY SHERRY B. ORTNER)}

\author{
Bishnu Prasad Dahal ${ }^{*}$
}

\section{Background}

Descriptive approach and interpretive approach are the commonly used approaches in anthropological or cultural study. The descriptive approach/perspective help readers by describing the cultural phenomena associated with particular culture. The goal of interpretative approach/perspective is to interpret or to open the cultural events and phenomena into different meaning according to time, context and conditions. Among these two, first one tries to familiarize the readers with the particular culture while another tries to interpret the same culture into different situation with different meanings.

A symbol is something verbal or non-verbal, within a particular culture (language, communication/conversation, sign articulation) that comes to stand for something else. The verbal symbols are the linguistic, sign or some representation of certain meaning. There are non-verbal symbols, such as flags, dress, etc., which stand for a nation's representation. Holy water is a potent symbol in Roman Catholicism. As is true of all symbols, the association between a symbol (e.g. water) and what is symbolized (holiness) is arbitrary and conventional. Water is not

Mr. Bishnu Prasad Dahal is an Anthropologist and has been associated with the Department of Sociology/Anthropology, Patan Multiple Campus, Patan T. U., in a Capacity of Assitant Lecturer intrinsically holier than milk, blood or other liquids. Holy water is not chemically different from ordinary water (Kottak, 1994). Symbolic/Interpretive Anthropology as an alternative approach in anthropological theory or perspective was developed after 1960 s. There is no single paradigm of this theory or approach/perspective because symbolic/interpretive anthropology "as a level" was never used by its founding anthropologists, Clifford Geertz and Victor Turner. Advocating a different approach Symbolic/Interpretive anthropology or perspective criticizes the generalized view of culture as suggested by Functionalists in answering questions like, How does institutions help to fulfill the needs of the society? How is social life possible? What keeps society in equilibrium/order? Functionalists find the solutions of these questions, however, they cannot interpret the symbols of the culture. Symbolic Anthropology claimed that we can understand whole functional phenomena using cultural materialism because all cultures have different symbols.

Symbolic/Interpretive Anthropologists offer different views of culture asking about meanings of symbols and how these symbols shape people's way or patterns of life. So anthropologists, rather than describing the culture, must dig out the meaning of the symbols that constitute the cultural whole. Culture is an abstract concept or adaptive strategy. Symbols used in every day life (in culture rituals, festivals and important social events etc.,) carry out the meanings for operation of the particular culture. Thus, investigation and interpretation of meanings used in the context of action (i.e. social action) is the primary concern of Symbolic Anthropology.

Culture is not something locked inside people's head but rather is embodied in public symbols - symbols through which the members of a society communicate their own view. It is value orientation ethos (characteristic features of any culture and community) to their further generations (by means of socialization). To anthropologists, they are social processes that pass from generation to generation. For example wearing white dress by a man symbolizes the death of his father or mother and 
the dress if wore by a woman symbolizes the death of her husband in Hindu culture.

For Geertz, reading culture is like doing archaeology; culture is exposed and explained layer by layer until it gives the significant meaning (i.e. interpretation understanding). By the interpretative understanding of culture, Geertz also implies the context (situation, time, condition) of the symbols used.

The interpretation of Balinese cockfight is a classical example of Symbolic Anthropology or interpretive approach. For Geertz, 'The Balinese Cockfight' is a symbolic event, which offers a window to Balinese culture through which it is possible to see "What keeps Balinese society in order? There are two contradictory relationships within the Balinese society. He interprets the event as a cultural "text" through which one attempts to understand the inner nature of Balinese society. The cockfight symbolizes the social relation (kin/village, community), conflict, rivalries between different communities and the social solidarity within a single Balinese community. Betting as a cockfight expresses the villagers' and kin's "wefeeling" which also relates to the existing labour, economic and ritual cooperation between the members. It is not only the fight between two animals (cocks) but also between the two communities in the "game form".

Before going to documentation of the task of religious rituals: first of all we have to define religion. Durkheim was perhaps the first sociologist to recognize the critical importance of religion in human societies. In his view "religion is a collective act and includes many forms of behaviors in which people interact with others". Durkheim initiated sociological analysis of religion by defining religion as a "unified system of beliefs and practices relative to sacred things". Compromising the definition put forward by Durkheim, I want to raise the question, "How can human societies be held together when they are generally composed of individuals and social groups with diverse interests and aspirations?" The probable answer may be that "religious bonds often transcend these personal and diverse forces". But readers may have further questions "Why should religion provide the societal glue?" Religion provides societal glue because it offers people meaning and purpose for their lives. It gives them certain ultimate values and end to hold in common. Although subjective and not always fully accepted, these values and ends help a society to function as an integrated social system. That's why people believe in religion either for "hope" or by "fear".

In fact religious rituals are practices required or expected of members of a faith. Rituals usually honour the divine power (or powers) worshipped by believers; they also remind adherents of their religious duties and responsibilities.

\section{Theoretical Perspectives}

Clifford Geertz - pioneering figure in the symbolic anthropology - recognizes anthropology as the science of culture. Geertz's interpretive anthropology claims to be a scientific study, however it must be able to excavate or dig out the meanings.

Symbols usually signify many things: to use Turner's phrase (The Forest of Symbols, 1967) they are multi-vocal. According to Geertz, human behaviour is fundamentally symbolic and therefore laden with meaning for social actors. The primary task of ethnographer is to understand the "webs of significance" which people themselves have spun.

Symbolic/interpretive ethnography focuses on the meaning of behaviour and rely primarily on verbal data in support of their interpretations. So, it is not inaccurate to say symbolic ethnographies have been similar to neo-structural in style.

Geertz in "thick description" argues the aim of anthropology is to interpret the meaning of behaviour to explain actions and attitudes that appear puzzling. According to him, culture consists of "structures of significance", "frame of interpretation" or "socially established structures of meaning". For Geertz, culture is "context" and it is the object of the ethnography to describe it.

Ortner's symbolic interpretation account of the Sherpa rituals thus provides a clear framework for conceptualizing the cultural-symbolism through Sherpa rituals. This frame provides 
the clear cut picture of interplay between the "idealistic" and "realistic" explanations of social and cultural Sherpa life because it reveals the abiding issue to be not one of the "anti-social behaviour" as opposed to their socio-cultural values (which is the "ideals" of Sherpas) but of "social behaviour" in society.

Ortner's symbolic interpretation persuasively demonstrates that explanation demands not simply discerning symbolic meanings of culture through particular events, but also accounting for how something as improbable for symbolic communication. Her work in general has sought to articulate a "common ground" as early interpretive/symbolic theorists hold.

Ortner's "Sherpa through their Rituals (1978)" aims to understand the nature of Sherpa society through an analysis of the meanings of certain rituals in Sherpa culture. As such it resembles Geertz's "cockfight" for the Balinese world. It also resembles Pritchard's structural analysis in "The Nuer". Ortner's goal in her ethnography is to "open" Sherpa culture to readers "unfolding it, revealing it, not only a sense of surface and rhythm, but also a sense of inner connections and interactions. She approaches her goals by focussing on rituals, because she claims that they are events that dramatize and make Sherpa social life intelligible for both participants and observer.

\section{The Argument of the Ethnography}

Ortner develops her analysis of the meanings embodied in Sherpa rituals by identifying the problems of Sherpa life. The basic problem of the Sherpas is the challenge to the social stability and social solidarity of communal life. The principles of Buddhism encourage tendencies towards isolation and atomization that she saw "threatening the fabric of Sherpa society".

The problem of social cohesiveness among the Sherpa is magnified by the lack of devices for conflict resolution. The Sherpas have "no formal mechanism of social control". It weakens the basis for community stability. So, with these fragile relationships within the community, nuclear families, and absence of formal institutions that deal with social control,
Ortner identifies the problem "What keeps things in order? Or "How Sherpa society possible?"

Ortner addresses these questions in two parts. She first claims that - the Sherpas depend on internalized constraints to prevent anti-social behaviors or disorder to maintain social order. However she observes, "inner constraints do not always constraint". Therefore, she looks elsewhere for the basis of Sherpa social order. In second part she finds it in their rituals: she concludes then that rituals resolve conflict by offering solutions to the problems. These solutions function psychologically. In this sense, rituals among the Sherpas serve the same function that cockfights do among the Balinese. The rituals are models of and models for social reality. Ortner's interpretation follows Geertz's paradigm "ritual manipulate and shape consciousness and they create meanings ... ...."

\section{Textual Organisation}

Ortner uses the first chapter to introduce the readers to the theory and methods of Symbolic Anthropology. In the second chapter, she states the analytical problems of her studythe problematic nature of the society and outlines the rituals that provide a means for resolving the conflicts and contradictions of Sherpa life and thereby contributes to social solidarity and stability. The next four chapters include the core of her symbolic analysis - the meaning of Sherpa rituals: (i) Nyungne; (ii) Hospitality; (iii) Exorcisms; and (iv) Offering rituals. The brief discussion on these rituals being suitable is presented here.

\section{Nyungne: Problems of Marriage, Family, and
Asceticism}

Ortner views Nyungne as the problem of marriage, family and asceticism. Four days holiday called Nyungne is observed once a year in late spring and involves "becoming like monks" to gain religious merit towards a good birth. The key vow of Buddhist asceticism is absenteeism from sexual relations. Nyungne is a period of atonement. It brings powerful merit to the participants. It involves fasting and abstentions experience, ascetic ethic voluntary participation purely on individual basis. Nyungne 
begins with "Sang" ceremony; at the first day volunteer-sponsors give a big evening meal to the participants. From second day, they recite Lamic text, taking refuse in the religion and they perform prostration, which is central to the observation of Nyungne.

From the "point of view of the Sherpas, the point of observing Nyungne is to get merit (Dharma). They follow abstention of food, drink and conversation, no sex, no work, no wearing of metal ornaments or leather. The rite is directed to the God Cherenzi (Avalokeshawor). Pawa Cheranzi is peaceful, compassionate God symbolizing that, initiating him grants salvation. God himself does not erode away the sin. Ideally, Nyungne is a best way to merit making, but how do problems arise in reality? Ortner claims that atomized family/closed household syndrome proves it that families are very closed and self-contained. A married couple by itself is responsible to have and rely on no one's support.

Cherenzi is the symbolic meaning of parental figure who created the world. In Sherpa society, male mercy and compassion are "feminine" attribute. So, perfect parent's sex brings marriage and marriage seems exciting but this pleasure will not last further. Marriage brings children and children bring joy but children fail to reciprocate in one's declining years. According to Ortner, Children's marriage pose threat at various levels in Sherpa society-

i. For mother, rupture of the "Nyinj Bond" (compassion bond)

ii. Hard economic realities - labor decreased, property divided and cattle shared

iii. Marriage at six distinct stages

iv. Old couple - depend on the son

v. Friction of two-in-laws

She acknowledges that the crisis of children's marriages and problems of the aged in Sherpa culture is a crisis of personal identity as well as of personal survival. All these issues were signaled by the symbolism of the Nyungne ritual.

All these problems are resolved by offering rituals (Nyungne). Symbolically it involves extreme condensation of complex and profound feeling and meanings. In fact, Nyungne transforms from worldly material life to merits of spiritual world. Nyungne offers satisfying refuge.

\section{Hospitality: Problems of Exchange, Status, and Authority}

Why hospitality is important in Sherpa society? Ortner believes that there is a lack of cohesion in Sherpa society. The key fact of Sherpa social structure is its relative atomization into nuclear family units. A household will give a formal hospitality at wedding, funeral, new year, etc. Hospitality is the most generalized form of "being social in Sherpa society". At the core of any hospitality event there is a material transaction: a host gives food to his guests. Feeding is culturally considered to be an act of great power and they are manipulative work. In "Yangzi" transaction, an individual brings a token gift of beer or food and asks for a favour. According to Ortner, the symbols of hospitality are to (i) maintain order in the status of hierarchy, (ii) produce order in the political functions of party interactions, and (iii) the reciprocity.

Ortner begins her account with an analysis of a ritual (Nyungne) that addresses strains within the Sherpa family. Ideally the Sherpa family is autonomous and self-sufficient, a closes unit, differentiated from and opposed to the rest of society. Its members are economically independent of other families, but dependent on one another and with strong ties to one another emotionally especially child and mother.

In contrast to these ideals, in reality relations within the Sherpa family are weakened (undermined) by several factors:-

(i.) Marriage: Children grow and got married and separated learning emotionally and physically.

(ii.) New family creation causes economic problems for the old ones resulting in division of land, labour and cattle.

(iii.) Conflict between mother-in-law and daughter-inlaw 
(iv.) The children take place for householder in place of aged parents (parents do not feel to accept children as adults and hence their decision.

This discrepancy (difference) between ideal and actual creates tension/conflict/dis-equilibrium/disorder that is supposed to be relieved in a ritual (Nyungne) atonement. It is supposed to help the elders see themselves not as deprived but as approaching religious/cultural ideal autonomy. Cognitively and emotionally, loss is transformed into gain.

The same forces of "atomism" disrupt relationships between families. Ortner argues that this threat is overcome by Sherpa belief about hospitality, "a way of being social" that is normatively governed by rules of "etiquette". Sherpas are reluctant (unwilling) to engage in the exchange of material goods suspicious (wary) of the attachments that it may generate. This attitude weakens social relationships - a situation that is overcome in the Sherpa customs of Yangdi and hospitality that facilitates to regain order or equilibrium. Yangdi is an institutionalized transaction consisting of a gift of food (or beer), which obligates its recipient to reciprocate with a favour of some sort. Ortner concluded that Yangdi is the basic mechanism for generating exchange in Sherpa society that hospitality, "dramatizes" order... ... produces order... ... and reproduces a mechanism, Yangdi - for generating order......."

In sum, in chapter three and four, Ortner addresses antirelational tendencies within and between families, the threat to family relationships and especially the feelings of less experienced by the elderly as the issues and the answer as embodied in the rituals of atonement. Between the families the issue is how to resolve the threat to communal relations associated with "atomism" and self-sufficiency, and the answer is embodied in the rituals of hospitality and institutionalized gift giving "Yandzi" to foster reciprocity between households.

But, even with these efforts to overcome the tendency toward atomism there are still obstacles to the maintenance of social order. As, Ortner argues, the "forces of anarchy and disruption periodically return in the form of demons to wreck, chaos and pollution in society. Therefore, she turns to an examination of the ritual mechanisms by which demons are controlled. She does this in the next two chapters: fifth and sixth. Chapter five describes the ritual of exorcism in which Sherpas directly confront, by symbolic means, the disruptive forces represented by demons. Chapter six describes rituals of offerings (oblation) in which Sherpas attempt through acts of giving similar to those of "Hospitality" to persuade Gods to assist them in combating the demons that plague them.

\section{Exorcism: Problems of Wealth, Pollution, and Reincarnation}

Exorcism held annually is connected with funerals. In exorcism there is always direct enactment of confrontation with the forces of evil. The "do dzongup" is a heterodox exorcism in which an effigy of tiger is made of mud and dough; a man leads it and the other rides dragging the tiger away in a room. It is placed on a plank and "road" is made of flour and driven away by the Lama with the music and scenting and is destroyed finally.

The Gyepshi rite is an orthodox exorcism. Rich people do it the opposite of "do dzongup" because they lavish the demons by valuable, beautiful and tasty offerings to pacify and gratify them rather than to threaten them.

Demons are insatiably greedy, vicious, and predatory creatures who roam the world causing troubles - illness, death, corruption and destruction. They are everywhere in the world. In Buddhist ideology, however, the demonic behaviour is the behaviour of the self. They should be driven away. Ascetic person defeat demons by learning to control "quiet" and ultimately eliminate these interior impulses. It is concentration and self-control. If demons are greedy for material wealth, luxury and satisfaction so are the peoples. They are to be eliminated.

\section{Offering Rituals: Problems of Religion, Anger, and Social Cooperation}

Offering rituals are done all-round-the year. The Gods are humanised, embodied in material world. Hen offering is observed. "Torma" is made, incense, music and sprinkling of 
beer invites the God. All phenomena or mechanisms of rituals act for maintaining the social order in fragile social relationships without any formal social institutions.

An exorcism ritual helps the individual to overcome the anxiety produced by anticipation of physical deterioration and death. And an offering ritual tends individuals have insight into their emotions, thereby producing a constructive way of dealing with their feelings of anger. Thus, the potential social disorder that might be created by "death" or "anger" are overcome by the rituals of exorcism and offerings and thereby the order is maintained in the Sherpa society. Therefore the phrase "Sherpa religion is the religion of fear" as used by writer seems more relevant in real life.

\section{Claims and Data}

The claims are repeatedly stated and systematically interwoven.

1. Textual arrangement is good.

2. The writer has included Sherpas' concepts, proverbs, myths, legends and native terms.

3. The argument of the monograph is nearly present.

4. All arguments of the book are essentially correct, sequentially presented and excellent theoretical interpretations.

\section{Evaluation}

There are some methodological pitfalls in spite of the good arrangement of photographs, drawings, verbal dialogue, dialects, etc. representing various facts. No clear-cut methodologies are addressed, so that graphical interpretation could not be found. Ortner's cultural interpretation or analysis of Sherpa culture from an internal or emic view is not possible by using traditional scientific methods of systematic observation, data collection and hypothesis testing used by pioneering anthropologists like Radcliff-Brown, Malinowski, Geertz, etc. The account of ritual scenes does not provide evidence for their alleged functions. Ortner presents no data about changes in attitudes or actions and about transformations. People are supposed to be experienced. The claims are simply stated and restated, again and again.

She could have shown some examples of where and how disorder was resulted due to less acts of hospitality and again solidarity was maintained through rituals.

Viewing Sherpa society only through their rituals can neither be understood at microscopic level nor can one analyze Sherpa social-cultural life in broader sense or macro level. The Sherpa society was studied with the help of the other perspectives also. For example Stevens Stanley studied the Sherpa society with the help of human ecological perspectives. His analysis focused on the Sherpa subsistence with the change in the environmental conditions. Thus analysis of Sherpa society only through their ritual is not enough to open the Sherpa society in the comprehensive or broader sense. The book has totally failed to analyse the Sherpa material life, Sherpa economy and environmental conditions. Her approach failed to try to analyse the material Sherpa culture while Julian Steward focused on the interplay among the population, economic subsistence, technology and environment. He argued that the relationship of the material components of culture is primary and non-material components of culture are secondary. So rituals only cannot play the prominent role for maintaining social order.

Thus, Ortner's account of the Sherpa based on a claim that they exhibit antisocial tendencies that are contained by their rituals is not grounded empirically. The conclusion could not be claimed as drawn from the "Sherpas through their rituals" as she has dealt with certain rituals only. The conclusions would have been different had that been drawn from "Sherpas through the weddings or any other institutions". For she herself says that weddings have contrasting interpretations.

Ortner views "marriage" as a problem in Sherpa life because marriage produces children and higher the number of children, less is the accessibility or availability of economic and environmental resource, social status etc, but Ortner ignores the polyandry marriage practices of Sherpa. It is not clear that they are either practicing polyandry marriage nor has developed other means. Many studies proved that population growth can generate 
dynamism and economic prosperity rather than problems or poverty. Growing population will adopt their changing conditions either by intensifying agriculture, adoption of probable cash crops, increasing use of marginal lands, developments of other sources of income or various kinds of fertility control if possible.

Just as there are no data to support Ortner's interpretation of the psychological function of Sherpa rituals, there is little evidence to support her view of problematic features of Sherpa society. She frequently used qualitative data rather than quantitative one. I think Ortner's idea is the synthesis of the idea of Functionalism and Symbolism as she uses the function of the rituals of the Sherpa society.

Her core analysis of "How Sherpa society is in Order? Or How Sherpa society is possible? Or Why Sherpas through their rituals, why not through other institutions?" etc. provide the clear picture in theoretical level. She claims that Sherpas society is atoministic; divided into isolated, antisocial nuclear families themselves composed of individuals whose view of human nature is fundamentally penurious (poor) avaricious (greedy), materialistic and emphatically egocentric. But, this view is not based on empirical facts.

Sacherer J. (1977) in his book "The Sherpa of Rolwaling: a Hundred years of Economic Change in Himalayas" has emphasized the adaptation of Sherpa to the harsh environment of Rolwaling valley. Ortner's arguments do not review Sacherer's analysis anywhere, even though his concepts, ideas, perspectives would definitely support her symbolic interpretation. Hence her idea, concepts and interpretation cannot be generalized and extended to all other Sherpa communities.

Similarly, Ortner ignored the new cultural adaptation of Sherpa's alternative cultural strategies. She has just expressed them by the process of change, but she did not try to explain the changing patterns of symbols in Sherpa life.

The disparity between the views of the Sherpas (insiders) and that of the analyzed project (outsiders) is another problem. For example, while Ortner sees Sherpa parties as full of competitions and tension; Sherpas describe them as having "fun".

Furthermore, she asserts that generosity is highly valued ... but rarely practiced. This discrepancy between ideals and self, between thought and action raises problem. Should Sherpas be interpreted in terms of how they are supposed to behave or in terms of how they actually behave?

\section{REFERENCES}

Bert, Patrick. (1998). Social Theory in the Twentieth Century, Polity Press in association with Blackwell Publishers, U.K.

Cuff E.C., Sharrock W.W., Francis D.W. (1990). Perspectives in Sociology, Third Edition, Unwin Hyman Ltd. London

Geertz, Clifford (1973). The Interpretation of Cultures, Basic Books Inc.

Kotak, Conrad Phillip (1994). Anthropology: The Exploration of Human Diversity, Sixth Edition, McGraw Hill Inc.

Ortner, Sherry B.(1978). Sherpas through their Rituals, Cambridge University Press

Ritzer, George (1996). Modern Sociological Theory, Fourth Edition, McGraw Hill Inc.

Turner, Victor (1976). The Forest of Symbols, Cornell University Press 


\section{FACULTY OF THE DEPARTMENT}

1. Rishikeshab Raj Regmi, Professor and Chairperson, Department of Sociology/Anthropology; Ph.D. (Anthropology), University of Calcutta.

2. Kailash Nath Pyakuryal, Professor and Former Chairman and Dean, Institute of Agriculture and Animal Sciences; Ph.D.(Rural Sociology), Michigan State University.

3. Chaitanya Mishra, Professor and Former Chairman; Ph.D. (Sociology), University of Florida.

4. Ram Bahadur Chhetri, Reader, Ph.D. (Anthropology), University of Hawaii.

5. Kiran Dutta Upadhya, Reader, M.S.(Rural Sociology), University of the Philippines (Currently enrolled in the Ph.D. program in sociology at West Bengal University).

6. Krishna Bahadur Bhattachan, Lecturer and Former Chairman; $\mathrm{Ph} . \mathrm{D}$. (Sociology), University of California, Berkeley.

7. Padam Lal Devkota, Lecturer; Ph.D. (Anthropology) Delhi University.

8. Om Gurung, Lecturer and Former Chairman; Ph.D. (Anthropology), Cornell University.

9. Phanindreswor Paudel, Lecturer; M.A. (Sociology); Banaras Hindu University.

10. Prabhakar Lal Das, Lecturer; M.A. (Sociology) Bhagalpur University.

11. Laya Prasad Uprety, Lecturer; M.A. (Anthropology), Tribhuwan University, M.S. (Social Development), Ateno De Manila University, the Philippines (Currently enrolled in the Ph.D. program in Anthropology at Tribhuvan University, Nepal).

12. Tulsi Ram Pandey, Lecturer; M.A. (Sociology), Tribhuvan University. M.S. (Social Development) Ateno De Manila University, the Philippines (Currently enrolled in the $\mathrm{Ph} . \mathrm{D}$. program in Sociology at Delhi University, India).

13. Bhanu Bhakta Timsina, Lecturer; M.A. (Anthropology), Tribhuvan University.

14. Youba Raj Luitel, Lecturer; M.A. (Sociology), Tribhuvan University, M.S. (Gender studies) at Institute of Social Studies, the Netherlands.

15. Surendra Mishra, Lecturer; M.A. (Sociology), Tribhuvan University.

16. Saubhagya Shah, Lecturer; M.A. (Sociology), Tribhuvan University, Enrolled in the Ph.D. Program in Anthropology at Harvard University.
17. Binod Pokharel, Lecturer; M.A. (Anthropology), Tribhuvan University.

18. Keshab Kumar Shrestha, Lecturer; M.A. (Anthropology), Tribhuvan University, (Currently enrolled in the Ph.D. Program in Anthropology at Tribhuvan University).

19. Samira Luitel, Lecturer; Ph.D. (Sociology), Edminton University, Canada.

20. Chinta Mani Pokhrel, Lecturer; M.A.(Anthropology), Tribhuvan University.

21. Pratibha Gautam, Lecturer; M.A. (Anthropology), Tribhuvan University (On Deputation in Padma Kanya Campus).

\section{PART TIME FACULTY}

23. Dilli Ram Dahal, Professor; Ph.D.(Anthropology), University of Hawii (Part Time from CNAS).

24. Sunita Upreti (Banstola), Assistant Lecturer; M.A. (Sociology), Tribhuvan University, MS (Sociology), Michigan State University, USA.

25. Janak Rai, Assistant Lecturer; M.A. (Anthropology), Tribhuwan University (Part Time from Tri-Chandra Campus).

26. Dambar Chemjong; Assitant Lecturer; M.A. (Anthropology) Tribhuvan University, M. Phil. (Anthropology), University of Bergan.

27. Udhav Rai, Assistant Lecturer; M.A. (Anthropology), Tribhuvan University, M.S. (Applied Social Research), University of Manchester, London.

28. Suresh Dhakal, M.A. Assistant Lecturer; (Anthropology), Tribhuvan University, M.Phill.(Anthropology), University of Bergan, Norway.

29. Pasang Sherpa, Assistant Lecturer; M.A. (Sociology), Tribhuvan University (part time from Trichandra Campus)

30. Mrigendra Karki, Assistant Lecturer; M.A. (Sociology), Tribhuvan University (Part time from CNAS).

31. Man Bahadur Khatri, Assistant Lecturer; M.A. (Anthropology), Tribhuvan University, M.Phil.(Anthropology), University of Bergan, Norway.

32. Madhusudan Sharma Subedi, Assistant Lecturer; M.A. (Sociology) Tribhuvan University, M.Phil. (Anthropology), University of Bergan.

33. Shambhu Kattel, Assistant Lecturer; M.A. (Sociology) Tribhuvan University, M.Phil.(Anthropology), University of Bergan. 
34. Ram Bahadur K.C.; Assistant Lecturer; M.A. (Anthropology), Tribhuvan University (Part time from Patan Campus).

35. Shamu Thapa, Assistant Lecturer; M.A. (Anthropology) Tribhuvan University, M.Phil. (Anthropology), University of Bergan.

\section{ADMINISTRATIVE STAFF}

1. Sulochana Thapa - Assistant Administrator

2. Prem Shrestha - Accountant

3. Krishna Karki - Office Assistant

Ram Bhakta Karki- Peon.

Rakesh Maharjan - Peon.

\section{OCCASIONAL PAPERS PUBLICATIONS \\ VOL.1}

1. Nepal School of Sociology/Anthropology

Dor Bahadur Bista

2. Sociology and Anthropology Curriculum and the Needs of Nepal

Krishna Bahadur Bhattachan.

3. "Romanticism" and Development" in Nepalese Anthropology James F. Fisher

4. Migration, Adaptation, and Socio-Cultural Change : The Case of the Thakalis in Pokhara

Ram Bahadur Chhetri.

5. Native Strategies for Resource Management

Om Prasad Gurung

6. Natural Causes and Processes of Poverty in Micro Settings Tulsi Ram Pandey

7. Factors Associated with Occupational Sociolization in Rural Nepal

Kiran Dutta Upadhyay

8. Development and Underdevelopment : A Preliminary Sociological Perspective

Chaitanya Mishra

VOL. 2

1. Sociology and Anthropology : An Emerging Field of Study in Nepal

Om Gurung

2. The past and Future of Sociology in Nepal

Bishnu Bhandari

3. Some Sociological Reflections on Development in the Eastern Himalayas

Gopal Singh Nepali

4. Economic Modernization in a Chepang Village in Nepal Ganesh Man Gurung

5. Culture and Resource Management for Subsistence : An Anthropological Perspective

Bhanu Timseena

6. A Socio-economic profile of the Porters in the Central Mid-Hills of Nepal

Kiran Dutta Upadhyay

7. Employment, Working Conditions and Mode of Living: The Case of Nepali Watchmen in Bombay 
8. Television and the Child in Nepal : An Assessment of Viewing Patterns

Dyuti Baral

9. Mercantilism and Domestic Industry in West-Central Nepal : Significance for Anthropological Study of the Community

Stephen L. Mikesell and Jamuna Shrestha

\section{Vol. 3}

1. Forestry and Farming System in the Mid-Hills of Nepal

Kiran Dutta Upadhyay

2. Socio-Economic and Cultural Aspects of Aging in Nepal

Rishikeshab Raj Regmi

3. Religion, Society and State in Nepal

Dipak Raj Pant

4. Community Development as Strategy to Rural Development Kailash Pyakuryal

5. National Integration in Nepal

Ganesh Man Gurung and Bishnu Bhandari

6. The failure of Confidence Mechanism

Tulsi Ram Pandey

7. Building a New American Academic Anthropology

Tom Cox

8. Afro-American Sociologists and Nepali Ethnography

Stephen L. Mikesell

9. Case Studies on Domestic Servants: Reflection on Rural Poverty Saubhagya Shah

\section{VOL. 4}

1. Anthropology, Development and Public Policy

\section{Gerald D. Berreman}

2. Development Issues Raised during the "People's Movement" of 1990

Krishna B. Bhattachan

3. Anthropological Perspectives on Grassroots Development in Nepal

Padam Lal Devkota

4. Deforestation and Rural Society in the Nepalese Terai Rishikeshab Raj Regmi

5. The Current Socio-Economic Status of Untouchables in Nepal Thomas Cox

6. Group Process for People's Participation in Rural Nepal :

Reflections from a Micro Level Study

Youba Raj Luitel
7. Sherpa Buddhists on a Regional Pilgrimage : The Case of Maratika Cave a Halase

Eberhard Berg

8. Book Review

Hemant Humar Jha

VOL. 5

1. Ethnicity and Nationalism in the Nepali Context

A Perspective from Europe

Uwe Kievelitz

2. The issue of National Integration in Nepal

An Ethnoregional Approach

Krishna B. Bhattachan

Kailash N. Pyakuryal

3. Bheja as a Strategic Cultural Convention

Community Resource Management in the Barha Magarat

Suresh Dhakal

4. The Rajbanshis of Rajgadh

Community Adaptation in the Enviroment of Eastern Terai Hari P. Bhattarai

5. Kurma, Kola, and Kuri as Community Concepts

Patrilineage, Deities, and Inside-Outside Dichotomy among the

Rana Tharus

Ganesh M. Gurung

Tove C. Kittelson

VOL. 6

1. Forest, People's Participation and Conflicts in Nepal

Dr. Rishikeshab Raj Regmi

2. Restoration of Democracy and People's Empowerment in Nepal Prof. Kailash N. Pyakuryal

3. People-centered Development in Nepal: an Innovative Approach Dr. Padam Lal Devkota

4. Functions of an Organization in a Indigenous Irrigation System: A Case Study from a Hill Village in Nepal

Laya Prasad Uprety

5. An Analysis of The Rural Poverty From People's Perspectives: A Case Study from Amarpur VDC of Panchthar District Binod Pokharel

6. Environmental Pollution and Awareness in Pokhara City: A Sociological Perspective Dr. Biswo Kalyan Parajuli 
7. An Anthropological Perspective on Shifting Cultivation: A Case Study of Khoriya Cultivation in the Arun Valley of Eastern Nepal

Suresh Dhakal

8. Social Engineering Approach to Air Quality Challenge: The Case of Kathmandu

Ramesh C. Arya

VOL. 7

1. Anthropological Insights in the Delivery of Health Services in Nepal Prof. Rishikeshab Raj Regmi

2. Weberian Model of Social Stratification - A Viewpoint - Prof. Dr. Kailash Pyakuryal

3. Anthropology, society and Development in Nepal : A Native Perspective Dr. Padam Lal Devkota

4. Population Dynamics and Environmental Degradation in Nepal : An Overview Laya Prasad Uprety

5. Gender Roles and Activities Among the Rural Poor Households : Case Studies from Hill Villages Mr. Binod Pokharel

6. Exclusion, The Politics of Location and women's Property Rights Debates in Nepal : A Discourse Analysis of Political Activism Yauba Raj Luintel

7. The Social World of Nepalese Women Dr. Samira Luitel

8. Cultural Dimension of Pasture Resource Management in Nepal: A Study of Gumba System of the Northwest Dolpa Mr. Dhirendra B. Parajuli

9. Emerging Methods in Research Participation and Empowerment Processes in Nepal Dr. Philip Tanner

\section{NOTES TO CONTRIBUTORS}

Occasional papers on Sociology and anthropology publishes articles, original research reports, review articles, book review, dissertation abstracts, professional announcement, and other information of interest in the areas of the sociology and anthropology of Nepal and other Himalayan regions. Both the Nepalese and foreign scholars may submit their articles.

Materials submitted should be in English or in Nepali. Authors must take full responsibility for the originality, contents, and opinion expressed in these articles. The copyrighted material which is to be reproduced in the articles must be suitably acknowledged.

Contributors are requested to send, if possible, their material on computer floppy disks using IBM compatible word processing programs. They may, however, send copy of the manuscript separately. The text, notes, and references should be typed double -spaced. All pages should be numbered. The title of the paper, author's name, affiliations, and complete address should appear on the first page.

The anthropological style of referencing is preferred. Texts should refer to notes numbered consecutively. All notes and footnotes should appear at the end of the paper. Book reviews should not, however, contain footnotes; all references should be incorporate in the text itself.

Citation in the text should include the author's surname, year of publication, and page number. e.g. : (Sorokin, 1978:49). If the publications to be cited is authored by more than two persons, then use the surname of the first author, to be followed by et al. If the same reference is cited more than once continuously, use ibid. After citing the full reference once, but giving the relevant page number if it is different.

Entries for the bibliographical list should follow the following order author's name (surname, followed by full first name or initials), year of publication, the title of publication along with its edition number, place of publication, and publisher's name. If the reference is to an article form an edited book, then give the name of the author as suggested above, year of publication, the title of the article, the title of the book, editor's name, place of publication, and publisher's name; e.g. Greenwold Stephen 1978. "The Role of the Priest in Newar society". Himalayan Anthropology ed. James Fisher The Hague : Mouton.

If the reference is from a periodical, give the name of the author as suggested above, year of publication. the title of the periodical with its volume number, and page number : e.g: Gray John. N. 1980, "Hypergamy, Caste and Kinship among the Chhetris of Nepal". Contributions to Indian Sociology, 14: 1-34.

If the year and the place of publication are missing use n.d. and n.p. respectively. The bibliographical list should preferably include only the works cited. Use double quote marks (" ") while quoting sentences and single quotes (' ') for a single work/phrase. Use spellings as followed in the New Webster Dictionary or Oxford Dictionary. Contributes are requested to maintain consistency throughout their articles.

All correspondences related to editorial and subscription should be to :

The Chairperson

Central Department of Sociology/Anthropology

Tribhuvan University

Kirtipur, Kathmandu 